\title{
Emergence of Non-Traditional Financial Service Providers in the Market - A Threat or An Opportunity for the Georgian Banking Industry
}

Tea Kasradze

Professor at Caucasus International University

\section{Abstract}

Each banking institution has a customer-oriented strategic plan, although the sudden emergence of competition does not allow them to relax. The explosion of new technologies and the rise in consumer demand have been putting pressure on banks since the 2008 recession. Retail banking customers are constantly expecting new, improved, affordable, convenient continuous service from the bank. In an environment of increasingly competitive, innovative financial services, banks need to be able to maintain not only customers but also brand awareness. The emergence of non-traditional financial service providers in the market such as FinTech, NEO Banks, Challenger Banks, BigTech, which reduces the relationship between banks and their customers, completely changes the banking industry. Today we face a new open ecosystem of consumers, traditional banks, FinTech and BigTech companies, regulators, developers, non-banking firms and other players, with customers at the center. Banks will have to significantly change their commercial and operating models to retain customers and remain active players in the market. The presented paper examines the development trends of new players in the financial industry - non-traditional financial service providers and the readiness of the banking industry to respond to these trends. The paper is a study of the impact of digitalization of financial services on the banking sector based on the study and analysis of reports of the various international organizations, local policy documents, reports and regulations of the National Bank, the papers of various researchers and their secondary data. Based on the research, suggestions have been made on how Georgian banks should strategically approach non-traditional providers of financial services to avoid losses, withstand competition and remain active market players.

Keywords: BigTech, FinTech, bank industry, financial services, consumers, digitalization, open banking 


\section{Introduction}

The internal (micro) and external (macro) environment of banking institutions, which determines the competitiveness of the banking sector, has changed significantly since the 2008 crisis. Among the major recent micro-changes that have undoubtedly changed the bank operations and vision are: a) the emergence of a new generation of banking customers and increased customer expectations and b) increased competition from new players in the financial industry - non-traditional financial service providers - FinTech, NEO Banks, Challenger Banks, BigTech (SWACHA-LECH, 2017). They are focused on the new generation of consumers and their expectations. These changes are forcing the banking sector to significantly change its commercial and operating models in order to retain customers and remain active players on the market. The trend accelerated even more in the wake of the Covid-19 pandemic.

The emergence of a new generation ${ }^{1}$ of customers (Generations $\mathrm{Y}$ and $\mathrm{Z}$ ) and rising new customer expectations are pushing large banks to completely change their approaches. New generations are constantly demanding the services offered to be refined, and they expect more from financial institutions than their previous generation.

Generation Y- the so-called Millennial Generation - was born in 1981 - 2000. This generation cannot imagine their own home without technology. Millennials believe that they are changing the world. They will probably succeed. They have already overtaken Generation X in the labor market.

Soon Generation Z born in 2000-2020 (the so-called iGen) will catch up with this generation. As of today, Generation $\mathrm{Z}$ members are under the age of 20, so at this point, it is difficult to analyze their financial habits and behavior. However, it is important for banks to start monitoring the behavior of Generation Z, of the youngest customers whose demand for banking services will undoubtedly increase gradually in the coming years.

It seems that identifying the needs of Generation Y, (the so-called Millennials) and Generation Z (the so-called iGen) based on their age, number, and technological interests is very important for today's banking business. This generation is now young and becoming new users of financial institutions. These are the young generations who are constantly striving for innovation. This is a generation that is important both in size and in their great demand for banking services. The younger generation, unlike

${ }^{1}$ Generation - A group of people born 20 years apart who have three similar criteria:

- They are intersected in one historical epoch. They have to experience the same historical event or social change in a similar age category;

- They have similar attitudes and patterns of behavior.

- Based on similar experiences, they are combined with a sense of belonging to a generation (Strauss \& Howe, 1997) 
the older generation, grew up in a different society, culture, religious beliefs and formed their own, different behaviors and attitudes from the older ones towards various issues, including finances.

Six out of five millennials surveyed say they prefer to communicate through social media; According to the survey, millennials make up the largest percentage of mobile banking customers - $47 \%$. Given this trend, banks need to pay close attention to the expectations of generations. They should expect that future generations, starting with Gen Z, will invest even more in technology and increase their demand for relationships with the bank through various technology channels. For comparison, Baby Boomers and senior members of Gen X, as a rule, value human relationships and prefer to physically go to bank branches and settle their affairs on the spot (Wingard, 2018). This is a challenge for banks, as they must be able to meet the expectations of both older and younger generations of bank customers at the same time so as not to hurt the expectations of investors. Interested parties should be aware that they will receive a return on their investment or equity. To do this, banks must make a profit. This in turn is related to customer expectations. Satisfied customers are the key to business success - the more satisfied customers are, the more satisfied investors will be.

It is difficult for traditional banks to cope with this challenge. Non-traditional providers of financial services are the ones who fill the gap that exists between the expectations of the customers and the services offered by the traditional banks. The reason why customers buy services from non-traditional providers of financial services is the speed of services, cheapness and customized service. The absence of intermediaries is the biggest tool of FinTechs (PwC, 2016).

\section{Research Methodology}

The presented paper examines the development trends of new players in the financial industry - non-traditional financial service providers such as FinTech, NEO Banks, Challenger Banks, BigTech. Etc and the readiness of the banking industry to respond to these trends. The paper is a desk study of the impact of digitalization of financial services on the banking sector based on the study and analysis of reports of the various international organizations, local policy documents, reports and regulations of the National Bank, the papers of various researchers and their secondary data. Based on the research, suggestions have been made on how Georgian banks should strategically approach non-traditional providers of financial services to avoid losses, withstand competition and remain active market players.

\section{Literature Review}

The landscape of most industries has changed dramatically in recent years, affecting both existing and start-up companies. In such an environment, traditional approaches to management are outdated and need to be re-evaluated in order for companies to 
remain competitive. Financial industry experts point out that financial institutions operating today are experiencing increasing global pressure not only from fintech and digitalization, but also from new disruptive entities such as social media platforms, eretailers, robotics, tech companies, startups, artificial intelligence and large ICT. Changes in consumer behavior and industry regulation are also to be considered, and transformational changes are needed instead of improving existing processes. More than $80 \%$ of banking leaders believe that their business is in jeopardy and that revolutionary newcomers are changing institutional logic in a way that threatens existing actors. While managers of operating companies generally acknowledge the threat, many businesses are finding ways to manage it. Some operating financial institutions are not even in a hurry to take drastic, radical measures because they believe that they are operating in a sufficiently highly regulated market. However, this market is now approaching the level where competition intensifies and not everyone can survive (Strandvik, Holmlund, \& Lähteenmäk, 2018).

The emergence of new generations and their dependence on technology has greatly contributed to the emergence and rapid growth of Fintech and Bigtech companies on the market. Today, the number of FinTechs on the market and the number of customers of their innovative financial services tailored to their customers is growing. Increasing competition from FinTechs is one of the major challenges facing the banking industry today. There is no doubt that at the present stage Fintech companies have a great impact on the competitiveness of the banking sector. FinTech companies are typically start-up firms that focus on using software to deliver financial services. Fintechs are growing at lightning speed on world markets due to low cost, speed and other positive factors. The market capitalization of 10 leading American Fintechs increased by $50 \%$ in 2018. Goldman Sachs predicted that the annual revenue of these startups would exceed $\$ 4.7$ trillion, which will be mainly at the expense of traditional financial service companies. These new members of the industry are forcing many financial institutions to look for partners and/or merger opportunities to avoid the financial problems caused by Fintech competition (Tea Kasradze, 2017). In order to stay competitive, traditional banks and credit unions need to learn from FinTechs who have achieved success/customer confidence by providing them with streamlined services. (Wingard, 2018).

During the Covid-19 pandemic, the number of users of Fintech services increased even more. E.g. Within 6 months of the pandemic in the USA, the number of users of Fintech services increased by $6 \%$ to $42 \%$ (before the pandemic $36 \%$ of financial decision-makers said they used Fintech accounts). If we look at it in terms of generations, the number of Fintech users increased by $14 \%$ in Generation Z, by $8 \%$ in the Millennials, by $7 \%$ in Generation X and by $2 \%$ in Baby Boomers (Krivkovich, White, Townsend, \& Euart, 2020). 
Fintech companies provide financial services through computer software and technologies so that customers can plan, manage and control their own finances more easily and quickly. This ensures informing the customer timely, which in turn reduces costs and improves existing business models and services. Online mode offers customers a wide variety of financial product choices and gives them more independence. Also, with the help of technology, financial organizations have more detailed databases about their customers. Accordingly, they offer the client the most favorable and acceptable product/service (Alfaidze, 2019).

Fintech's operations include financial management, payments, international transactions, cryptocurrency, blockchain, loans and deposits, Peer-to-Peer (P2P) loans, investments, financial markets, trading and risk management.

Fintechs are an alternative to banks in terms of financial services. They try to offer customers much-simplified savings or lending services. For example, the depositor app automatically saves money after each payment. The simplicity of the process and the result fascinate the customer. Fintechs also issue loans much more easily than banks. A P2P loan platform connects the borrower and the lender without a financial intermediary. A P2P platform can provide services such as search, screening, evaluation, payment processing and execution or escrow deposit with a third party until certain conditions are met. The loan is issued through P2P at the interest rate indicated on the website at any time, continuously. It is a flexible and easy alternative to finding resources, making it popular with both startups and students.

When a third party is not involved in the transaction, there is a greater risk that the service provider will not provide the service at all or its quality will not be what the customer expects, or the buyer will be insolvent, or one or both parties will benefit from asymmetric information. This additional risk represents the additional transaction costs for the P2P transaction. The buyer, seller, or both may pay the price of the service or may offer the service for free and generate income in another way (Meparishvili, 2019).

P2P lending platform works on the principle of quick identification and elimination of risks from both parties. The platform determines the interest rate based on the risk assessment of the individuals wishing to borrow. When using the P2P platform, the lender is guaranteed no losses if the borrower is late in paying. The lender is also insured against currency risks as the investment is made only in hard currency.

The emergence of serious competitors in the form of Fintechs and the technological innovations introduced by them in financial services are forcing the banking sector to change the traditional accumulation and lending practices. Today, banks have started to actively provide financial services through mobile, Internet and various software applications. Bank customers can use their mobile phones to control their financial funds, promotions, stocks, make daily transfers, manage insurance and conduct other financial transactions. 
Another serious competitor to the banking sector on the market is Bigtech companies (the term Bigtech combines Big and Technology to highlight the names of the world's largest technology companies). BigTech firms - large companies of established technology platforms - are playing an increasingly important role in the financial system and have begun to provide financial services (FSB, 2019). Over the past decade, some BigTech companies have grown rapidly and today are larger in terms of both the number of customers and the amount of capital than the world's largest financial institutions.

The difference between Bigtechs and Fintechs is mainly related to equity. Bigtechs are owners of large capital, own more advanced technologies, and are more widely represented around the world. Fintechs are firms created specifically to provide financial services, financial services for Bigtechs are a small part of their broader business. Bigtechs have a major business in information technology and consulting, from which they receive $46 \%$ of income, and income from financial services accounts for about $11 \%$ of total income (BIS, 2019).

Bigtechs have access to a large amount of user data which allows them to "swim in" the financial market. BigTech firms benefit from building existing large customer databases and collecting or analyzing their customer data (FSB, 2019). They can use this to quickly reach a scale in a variety of business areas, including financial services. They also have significant financial resources and often have access to capital and financing at a lower cost than some large financial groups (FSB, 2019).

It should be noted that by the end of 2019, the market capitalization of the 200 largest banks was only slightly higher than the market capitalization of the seven largest BigTech companies (Amazon, Facebook, Microsoft, Google, Tencent, Alibaba, Apple) and the capitalization of both groups was about $\$ 6$ trillion. Such a large difference is not surprising, as the price-to-book ratios of Bigtechs were more than 5.0 throughout 2019, while the price-to-book ratios of banks varied in the range of 0.8 to 1.2 over the last ten years. In 2020 this gap widened further. By the end of July, the market capitalization of only the seven largest BigTechs exceeded $\$ 8$ trillion, which was almost twice the market capitalization of the top 200 banks (Mckinsey\&Company, 2020). Investors also seem to prefer technology over banks.

When discussing competition or cooperation between the banking sector and nontraditional providers of innovative financial services, we can not ignore the open banking system.

Over the past decades, there have been many startups in the banking and financial sectors that are often better able to introduce digital financial innovations than banks. However, often such startups are either not ready or do not want to become a bank. In order to promote this competition, an initiative was launched in Europe to oblige banks to make information about the client's bank accounts, payment implementation, etc. available to these companies. The bank is obliged, at the request 
of the customer, to give a third party access to his/her information - this may be another application, startup, etc. Open Banking allows customers to use a range of services whereas these services are not offered by their preferred bank. Open Banking, on the one hand, increases competition on the market between traditional and non-traditional financial institutions, on the other hand, it has become a major catalyst for innovation in the banking sector as it paves the way for easier access of global platforms to the sector. Open Banking in Europe is regulated by PSD2 (Payment Services Directive 2). Since 2019 there are 474 registered institutions in Europe that are involved in open banking (BOG Fintech, 2021).

\section{Discusion and Findings}

Experts believe that in recent years, Georgia has made great strides in terms of technology, and today we can say that Georgia is one of the most attractive places for Fintech opportunities in the post-Soviet space. Georgia is an attractive place for the world's largest Fintech companies to invest, as they see that many large companies are already operating successfully in the country. There is a great variety of Fintech companies in Georgia. Innovative financial services are successfully offered to customers here by both newly established startups and large companies providing traditional financial services. The banking sector in Georgia quickly realized the need and importance of financial innovation for consumers and it began to provide online banking programs to customers in cooperation with Fintechs, through which customers can easily perform various operations in a short time.

Today there are payment provider companies, as well as lender and cryptocurrency trading platforms in Georgia. Since 2018, the first Georgian neobank, fully digital bank Space Bank has also operated, only as a mobile application, without any traditional physical branches. Through this app, customers can get a full range of retail banking services such as loans, payment cards and saving products. The customer-oriented daily banking system has completely changed the access of the Georgian population to financial services and boost financial inclusion (Kasradze, 2020).

The number of online transactions with payment cards is gradually increasing. Ecommerce is also quite popular in the country. In Georgia, consumers often use ecommerce websites such as eBay, Amazon and AliExpress to purchase items through e-wallets and credit card payments. Consumers today can also avail P2P loans.

Unfortunately, no Fintech market research has been conducted in Georgia at present. Official statistical information, the analysis of which would confirm the success of Georgia in the revolutionary development of innovative financial technologies given in the above information, is scarce. The probable reason for this is that it is difficult to define the boundaries of Fintech services, which makes it difficult to quantify the market size of Fintech services. An additional problem is the difficulty of separating/differentiating Fintech services from other services by traditional financial sector companies. 
According to the Georgian FinTech Association, the Georgian FinTech Ecosystem currently has 25 FinTech companies, which is not much. See Fintech Ecosystem on Diagram 1:

\section{FinTech Ecosystem of Georgia}

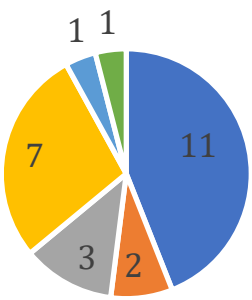
- Financial Solutions
- E-comerce
- other

- Cripto Currency, Blockchain

- Payments

- Banks

Source of Informatin: FitTech Assosiation of Georgia https://nbg.gov.ge/en/media/news/panel-discussion-on-open-banking And the percentage distribution of Fintech companies in Fintech ecosystem are presented in Diagram 2:

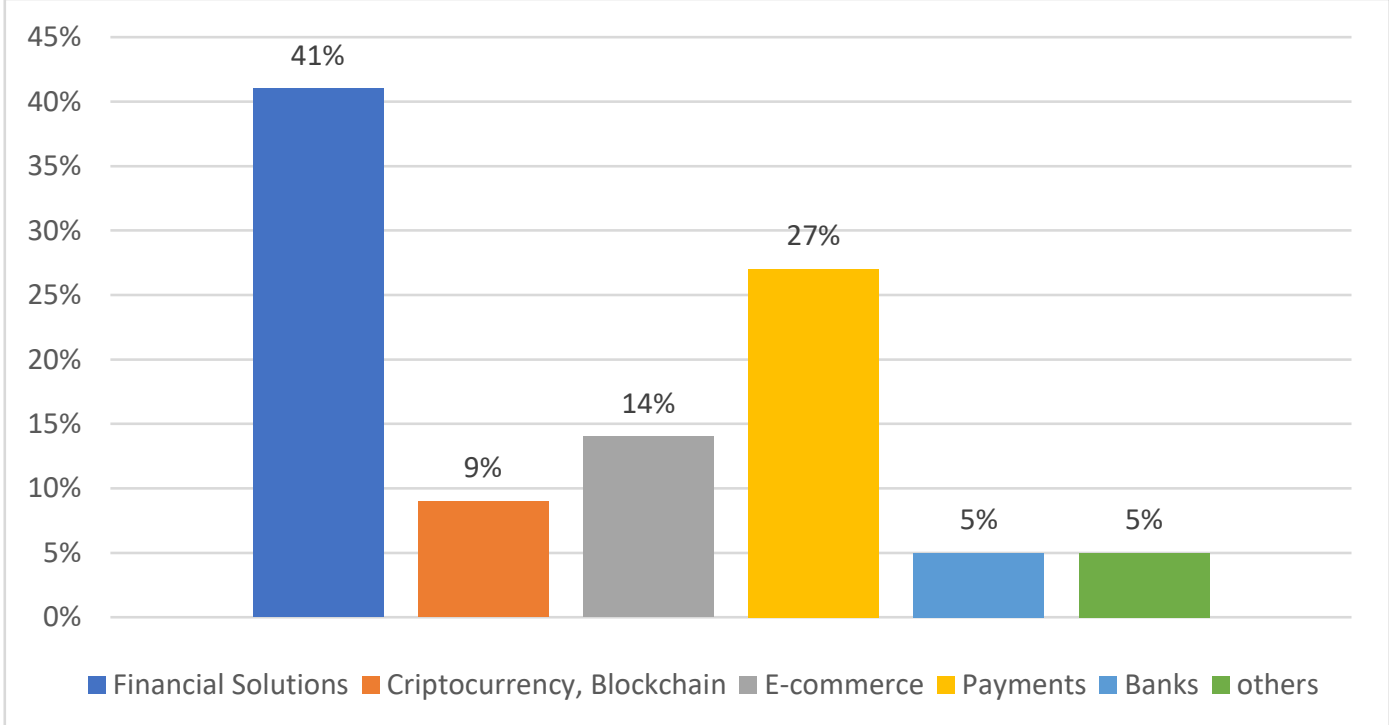

Source of Informatin: FitTech Assosiation of Georgia

https://nbg.gov.ge/en/media/news/panel-discussion-on-open-banking 
By 2015, the volume of online alternative finances in Georgia amounted to 103 million euros. In 2016, the volume of alternative credits in Georgia was 113 million USD, in 2017 it increased to 196 million USD, while in 2018 it decreased to 193 million USD. Alternative credits include the sum of Fintech credits and Bigtech credits, however, the volume of Bigtech credits in Georgia is equal to 0 and this indicator is the total volume of Fintech credits. (Giulio Cornelli, Jon Frost, Leonardo Gambacorta, Raghavendra Rau, Robert Wardrop and Tania Ziegler, 2020).

According to the National Bank, today 93 active payment service providers are registered in the market. However, the delivery of innovative financial services is not limited to a new, independent company, and is often done under the umbrella of existing organizations. Since banks and microfinance organizations are also aware of the importance of technological innovations in their business they are making significant investments in the development of financial technologies (Kasradze, Tea; Zarnadze, Nino, 2019).

The main challenges of the innovative financial service industry in Georgia are:

A) The main obstacle to the development of a competitive market in Georgia is the lack of clear regulatory standards. Regulations are somewhat hindering the activities of Fintechs. The permission/license from the National Bank is required for the activity. In case of a payment system provider, the requirements for obtaining a license are relatively light, while Fintechs wishing to lend and obtain a deposit will be required to obtain a digital banking license from 2020.

The introduction of an open banking system, on the one hand, will encourage the expansion of Fintech activities, on the other hand, will significantly change the traditional banking business models and keep the hegemony of the classical banking system in the past (Abuladze, 2018).

Pursuant to the Association Agreement between Georgia and the European Union, the National Bank of Georgia started the introduction of open banking in Georgia in March 2021 within the framework of the implementation of the Second Payment Services Directive (PSD2 - Payment Services Directive 2) It will be fully operational by the end of 2021 and will be available to non-banking institutions as well as individuals, which, on the one hand, will increase competition between Fintechs and banks, and, on the other hand, will give them better cooperation opportunities (National Bank of Georgia, 2020).

B) Restrictions on access to data. Open Banking allows Fintechs to easily access client data and embed banking services in their digital products. As a result, the consumer will get the most customized and safe product for them. At this point, this service is only available to banks. For Fintech companies, the business environment is not so favorable in this respect. Up to now, the banking sector only exchanges credit information with one another through credit bureaus. 
C) Lack of trust in customers is another challenge for non-traditional financial service providers. Although the interest in technological innovations is high, a large part of consumers still prefers the services of large financial institutions, which is due to the relationship and trust established over the years. Newly established Fintech organizations need to gain the trust and goodwill of customers with high quality, fast, cheap and transparent service (Zarnadze \& Kasradze, 2020.

D) Qualified staff is also a problematic issue for non-traditional companies providing innovative financial services. To work in the field of Fintech, a person needs some knowledge in both finance and technology (Tea Kasrade, 2021). Due to the high level of education, this problem is less common in Europe and America, but in the developing world, adequate human resources are another challenge for nontraditional financial service providers. Access to an educated and cheap workforce in Georgia is a kind of advantage of Georgian Fintech companies (Tea Kasradze, 2018).

E) And finally, access to capital is a serious challenge not only for Georgian companies but for the whole world (the only exception in this regard is China) (Kasradze, Tea, 2018).

\section{Conclusions and recommendations}

Thus, after the crisis of 2008, there is an explosion of new technologies in the financial sector and an increase in consumer demand, which put pressure on traditional banks. Retail banking customers are constantly expecting new, improved, affordable, convenient continuous service from the bank.

Given the need and popularity of technologies, trends and their current/future impact on the financial sector should be considered. Banks, if they want to stay in the market and be competitive, must perceive financial technologies as the next stage of evolution and be actively involved in simplifying and improving financial services.

The traditional banking system will be able to overcome the growing competition from Bigtecs and Fintechs only through innovative technologies, offering continuous digital banking tailored to the customer; by increasing cyber security measures to prevent theft of all kinds of information or technological fraud; with digital signatures that replace the paper and ensure the authenticity of the user's signature that the signed documents are $100 \%$ legal and valid without the need to go to the office; by collecting and processing data to better understand customer requirements and needs, and offer customized products; by gaining reputation and trust through offering any financial product to customers easily, quickly and cheaply; by educated, qualified staff. 


\section{Bibliography}

[1] Fraile Carmona, a. González-Quel Lombardo, R. Rivera Pastor, C. Tarín Quirós, J. P. Villar García, D. Ramos Muñoz, L. Castejón Martín. (2018). Competition issues in the Area of Financial Technology (FinTech). Directorate General for Internal Policies, European Parliament. Retrieved from https://www.europarl.europa.eu/RegData/etudes/STUD/2018/619027/IP OL_STU(2018)619027_EN.pdf

[2] Abuladze, R. (2018). Digital money. Tbilisi: E-Government Research Academy.

[3] Alfaidze, E. (2019). Does Fintech pose a threat to financial market

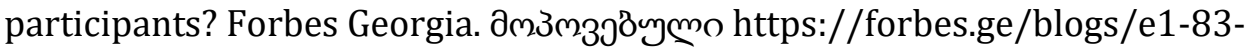
a3-e1-83-a5-e1-83-9b-e1-83-9c-e1-83-98-e1-83-a1-e1-83-97-e1-83-a3-e183-90-e1-83-a0-e1-83-90-e1-83-a4-e1-83-98-e1-83-9c-e1-83-a2-e1-83-94e1-83-a5-e1-83-98-e1-83-a1-e1-83-90-e1-83-a4/-cos6

[4] BIS. (2019). III. Big tech in finance: opportunities and risks, BIS Annual Economic Report 2019. BIS. Retrieved from https://www.bis.org/publ/arpdf/ar2019e3.htm

[5] BOG Fintech. (2021, June 9). What does Open Banking Change and What Opportunities do the Fintech Companies have from this Point. Retrieved from fintech: https://www.fintech.ge/news/details?id=163

[6] Capgemini; Efma. (2020). World FinTech Report 2020. Capgemini; Efma. Retrieved from https://fintechworldreport.com/wpcontent/uploads/sites/9/2020/04/World-FinTech-Report-WFTR2020_Web.pdf

[7] Dietz, M., Kincses, A., Rab, I., \& Andrade, B. C. (2020). Big techs versus big banks: Battle for the customer. Retrieved from https://www.mckinsey.com/industries/financial-services/ourinsights/banking-matters/big-techs-versus-big-banks-battle-for-thecustomer

[8] FSB. (2019). BigTech in finance - Market developments and potential financial stability implications. Retrieved from https://www.fsb.org/wpcontent/uploads/P091219-1.pdf

[9] Giulio Cornelli, J. F. (2020, November). Fintech and big tech credit markets around the world. Retrieved from https://voxeu.org/article/fintech-andbig-tech-credit-markets-around-world

[10] Giulio Cornelli, Jon Frost, Leonardo Gambacorta, Raghavendra Rau, Robert Wardrop and Tania Ziegler. (2020). Fintech and big tech credit: a new database. BIS. Retrieved from https://www.bis.org/publ/work887.pdf

[11] Kasradze, T. (2020). Challenges Facing Financial Inclusion Due to the COVID19 Pandemic. European Journal of Marketing and Economics, 3(2), 63-74. 
Retrieved from

https://journals.euser.org/files/articles/ejme_v3_i2_20/Kasradze.pdf

[12] Kasradze, Tea. (2018). Global Trends of Financing for Development and Georgia. International Scientific Journal of Business, 1, 34-45. Retrieved from https://www.researchgate.net/publication/331745749_Global_Trends_of_Fi nancing_for_Development_and_Georgia

[13] Kasradze, Tea; Zarnadze, Nino. (2019). Challenges of Economic of Georgia:

Good and Bad Economic Growth. European Journal of Economics and Business Studies, 5(1), 178-186.

doi:https://doi.org/10.26417/ejes.v5i1.p178-186

[14] Krivkovich, A., White, O., Townsend, Z., \& Euart, J. (2020). How US customers' attitudes to fintech are shifting during the pandemic. Retrieved from https://www.mckinsey.com/industries/financial-services/ourinsights/how-us-customers-attitudes-to-fintech-are-shifting-during-thepandemic

[15] Mckinsey\&Company. (2020). Big techs versus big banks: Battle for the customer. Retrieved from https://www.mckinsey.com/industries/financialservices/our-insights/banking-matters/big-techs-versus-big-banks-battlefor-the-customer

[16] Meparishvili, Q. (2019). Fintech Industry Challenges - What We Need to Know Before Thinking About a Startup. Marketer.ge

a. https://www.marketer.ge/fintec-industry-qeti-meparishvili/-œs 6

[17] National Bank of Georgia. (2020). Annual Report 2020.

[18] PwC. (2016). How FinTech is shaping Financial Services. PwC. Retrieved from

https://www.pwc.de/de/newsletter/finanzdienstleistung/assets/insurance -inside-ausgabe-4-maerz-2016.pdf

[19] Rabin, K. (2020, November 30). The Post-Soviet fintech landscape - the case for Georgia. Retrieved from https://www.finextra.com/blogposting/19585/the-post-soviet-fintechlandscape---the-case-for-georgia

[20] Strandvik, T., Holmlund, M., \& Lähteenmäk, I. (2018). "One of these days, things are going tochange!" How do you make sense ofmarket disruption? (I. U. Kelley School of Business, Ed.) Business Horizons(61), 477-486. Retrieved from https://reader.elsevier.com/reader/sd/pii/S0007681318300272

[21] Strauss, W., \& Howe, N. (1997). The Fourth Turning: An American Prophecy What the Cycles of History Tell Us About America's Next Rendezvous with Destiny. Crown.

[22] SWACHA-LECH, M. (2017). The main challenges facing the retail banking industry in the era of digitalisation. Journal of Insurance, Financial Markets and Consumer Protection(26), 94-116. Retrieved from https://depot.ceon.pl/handle/123456789/14336 
[23] Tea Kasrade, E. G. (2021). Challenges and Opportunities for Teaching Practical Skills at Higher Education Institutions under the conditions of COVID-19 Pandemic. European Journal of Social Science Education and Research, 8(1), 56-69. Retrieved from https://journals.euser.org/files/articles/ejser_v8_i1_21/Kasradze.pdf

[24] Tea Kasradze. (2017). Global trends of mergers and acquisitions. Challenges of globalization in economics and business (33. 239-245). Tsu. https://www.tsu.ge/data/file_db/economist_faculty/global.pdf-œs6

[25] Tea Kasradze, N. Z. (2018). Enhancing Workforce Competitiveness Through Improving Quality of Education - An Indispensable Means for Overcoming Poverty. International Journal of Innovative Technologies in Economy, 5(17), 19-21. doi: https://doi.org/10.31435/rsglobal_ijite/01062018/5654

[26] The Global Business Policy Council. (2019). Where Are the Global Millennials? Retrieved from Kearney: https://www.kearney.com/zh/web/global-business-policycouncil/article?/a/where-are-the-global-millennials-

[27] Wingard, L. (2018). Top 10 Banking Industry Challenges — And How You Can Overcome Them. Retrieved from https://global.hitachisolutions.com/blog/top-10-challenges-banking-financial-organizations-canovercome

[28] Zarnadze, N., \& Kasradze, T. (2020). Strong Organizational Culture - An Effective Tool for Companies to Survive in a Pandemic World;. European Journal of Language and Literature Studies, 6(2). Retrieved from https://journals.euser.org/files/articles/ejls_v6_i2_20/Zarnadze.pdf 